\title{
Study of attitudes of Kazan residents to the perspective of refusing the use of a personal car as a means of transportation in the city
}

\author{
Alsou Zakirova ${ }^{1, *}$, Guzaliya Klychova $^{1}$, Shaukat Khusainov $^{2}$, Zufar Zakirov ${ }^{1}$, and Ayaz \\ Zakirov $^{3}$ \\ ${ }^{1}$ Kazan State Agrarian University, 65, Karl Marx str., 420015, Kazan, Russia \\ ${ }^{2}$ Russian State Agrarian University - Moscow Timiryazev Agricultural Academy, 47, \\ Timiryazevskaya str., 127550, Moscow, Russia \\ ${ }^{3}$ Kazan (Volga) Federal University, 18, Kremlevskaya str., 420008, Kazan, Russia
}

\begin{abstract}
The article is devoted to the study of the attitude of Kazan residents to the prospect of not using a personal car as a means of transportation in the city. The aim of this study is to develop recommendations to popularize the idea of using public transport services of Kazan city residents on the basis of the analysis and its evaluation. To achieve the goal, the following main tasks were set and solved: a theoretical and empirical interpretation of the main concepts on the topic of the study; a comparative analysis of the volume of public costs from the use of a private car by residents of Kazan and their use of public transport services was carried out; the system of public transport in the city of Kazan was evaluated. The methodological tools of the study included a questionnaire survey and content analysis. As a result of the study, we found that at the moment there is indeed a problem within the city of Kazan, which consists in the impossibility of ensuring the universal transition of residents from the use of private cars to the consumption of public transport services, due to the lack of development of the relevant infrastructure.
\end{abstract}

\section{Introduction}

In the fall of 2020, the Ministry of Transport of the Russian Federation released an updated draft of the Transport Strategy, according to which the Russian government is considering a possible transition to free public transport in cities by 2035. Ministry of Transport of the Russian Federation proposes to introduce free travel on public transport provided the mechanism of «the user pays» for all categories of motorists. This scheme provides that in 2025 toll will be collected on roads of regional importance, and by 2035 from «all categories of road users», including the road network of urban agglomerations. According to this draft document, such a mechanism is needed «to stimulate the use of public transport and reduce the use of private transport in large cities.

\footnotetext{
* Corresponding author: zakirovaar@mail.ru
} 
But so far, public transportation has been less popular with Russian residents than personal transportation, according to a report on the implementation of the current transportation strategy, which was adopted in 2013. In 2019, the tendency of passengers leaving public transport continued, «despite the growing attractiveness of urban passenger transport systems and cab and carsharing services» [1-4], due to dramatically improved road conditions, especially in the European part of the country, which allowed the use of personal cars, both for business trips and for tourism.

Of course, after the acquisition of a personal vehicle a new owner of his own vehicle faces a significant number of problems, difficulties and inherent financial investments: the need for various types of insurance, the possibility of periodic getting into traffic jams, congestion and accidents, the need to change the summer tires for winter and back, the constant need to buy fuel, the need to check the technical condition and the usual routine maintenance, the obligation to registrar of the vehicle, the need to pay for the necessary technical condition of the vehicle, and the need for the maintenance of the vehicle. In addition, it has been scientifically proven that cars have a negative impact on the environment, and therefore on public health indicators. On the other hand, the use of a private car - a mobile alternative to public transport - is the possibility of free movement and the feeling of comfort of private space not only at home, but also in the vehicle.

To find out the prospects of plans to implement mechanisms to economically stimulate the influx of the population into public transport, it is important to conduct research on the attitude of residents of large Russian cities to the possibility of abandoning the use of private cars as the main means of transportation in their municipalities [5-8].

The problematics of the study can be defined as follows. The high public and personal costs associated with the maintenance of personal transport, as well as the interest of city authorities in reducing the number of vehicles within the city limits require the consideration of the readiness of the population to partially abandon the possession of a personal car. However, the absence of a worthy alternative in the form of public transportation makes such abandonment virtually impossible [9-11].

The purpose of this study is to develop recommendations to popularize the idea of using public transport services of Kazan city residents on the basis of the analysis and its evaluation.

To achieve the goal the following main tasks are set:

- to carry out theoretical and empirical interpretation of the basic concepts on the topic of the study;

- to determine and compare the amount of public costs from the use of a private car by residents of Kazan and their recourse to the services of public transport;

- to evaluate the system of public transport in the city of Kazan.

Considering the degree of scientific research of the problem of city residents' refusal to use a personal car within the municipality in favor of public transport, it should be noted that the theoretical and methodological foundations of the study of the service sector, which includes the activities of urban public transport, the prospects of development of urban public transport services and assessment of the quality of passenger service on urban routes are widely studied in the economic literature [12-15].

\section{Materials and Methods}

We will carry out clarification and interpretation of the basic concepts. The interpretation of the main concepts will consist of theoretical and empirical interpretations of the concepts.

\section{Theoretical interpretation of the concepts:}

1) The idea of refusal of the personal car - the concept, the essence of which consists in the complete/partial refusal of city residents to choose as a means of transportation in the 
territory of the municipality a personal car by resorting to the services of local public transport $[5,6,16]$;

2) The cost of using a private car - the costs of the consumer associated with the use of a personal vehicle, arising in the process of meeting the needs (in the movement) [17];

3) The cost of recourse to public transport services - the costs of the consumer associated with the use of public transport services, arising in the process of meeting the needs (in the movement) [18];

4) Quality of transportation services - a set of properties and indicators of the transportation process and transportation system that determine their compliance with regulatory requirements and the ability to meet certain needs of residents in accordance with the purpose of services [19];

5) Personal car - a car (most often a car, but it can also be an SUV, pickup or minibus), in which the driver goes on his own business. Such a car may be owned by the driver or may be rented [20];

6) Owner of a private vehicle - the owner of the vehicle, as well as the person who owns the vehicle on the right of economic management or the right of operational management or on another legal basis (right of lease, power of attorney to manage the vehicle, the order of the relevant authority to transfer the vehicle to that person, and the like).

7) Public (public) transport - a type of passenger transport as a sector that provides services for the transportation of people on the routes, which the carrier establishes in advance, bringing to the public the method of delivery (vehicle), the size and form of payment, guaranteeing regularity (repeatability of movement at the end of the production cycle of transportation), as well as the immutability of the route at the request of passengers [9];

8) Passenger transportation is the organized transportation of passengers and luggage, using specially equipped vehicles (cab, minibus, bus, trolleybus, streetcar, train, plane, ship) for certain distances [12];

9) Passenger transport - mass public transport that carries passengers on certain routes and is subdivided into street (streetcar, trolley bus, bus) and off-street high-speed (subway, high-speed tramway, monorail roads, conveyor transport); light road transport (taxis, departmental and private cars); two-wheeled transport (motorcycles, scooters, mopeds and bicycles); water transport (river «streetcar», motor and rowing boats, ferries); air transport (helicopters) [9];

10) Transport infrastructure - a set of all branches and enterprises of transport, both performing transportation, and providing their performance and maintenance, which includes a street and road network; off-street transport network (surface, overhead and underground); facilities for maintenance of transport facilities (parks and depots for parking, repair and maintenance of rolling stock, cargo terminals or stations, power facilities, railway stations) [21];

11) Shuttle cabs are buses and minibuses that carry passengers and luggage on established routes and are not fully integrated into the regular system of public transport;

12) Traffic flow is the movement of vehicles ordered by the transport network;

13) Economic efficiency is an indicator defined by the ratio of the economic effect (result) and the costs that generated this effect (result) [22];

14) Social efficiency is the conformity of the results of economic activity to the basic social needs and goals of society, the interests of an individual person [22];

15) Route is an established and equipped route of the rolling stock that performs regular transportation on the streets and roads, corresponding to the technical condition of the established requirements. The distinctive features of the route is the presence of stopping, control and technical points, equipped in accordance with the requirements; 
16) Route transportation is the transportation of passengers on established routes. Buses of different passenger capacity, trolleybuses and streetcars are used for route transportation;

17) Transport service schedule is a document establishing the time and (or) intervals of arrival of the rolling stock of off-street transport to the stations of off-street transport and (or) departure of the rolling stock of off-street transport from the stations of off-street transport [23];

18) Off-street transport line - a set of off-street transport infrastructure facilities used for transportation of passengers and carry-on baggage along the established route of regular transportation without transferring;

19) Off-street transportation infrastructure - a system of facilities, including off-street transportation tracks, stations, inter-station passenger crossings, electric depot, power supply, signaling, traffic control systems, communication networks, other devices, buildings and structures, including tunnels and ventilation shafts, designed to perform production processes, operation of non-street transport, temporary stay of people, movement of people and cargoes in the rolling stock of non-street transport, use as civil defense facilities, as well as machines, technological equipment, systems of machines and (or) equipment, units, equipment, mechanisms used in the operation of non-street transport;

20) Passenger means an individual who has concluded a passenger transportation contract with the carrier;

21) Carrier- a legal entity or individual entrepreneur who, under the contract of passenger transportation, has assumed the obligation to carry the passenger and carry the hand luggage by off-street transportation [23];

22) Personal mobility device - a device designed to move a person by using an electric motor (motors) and (or) human muscular energy (roller skates, scooters, electric scooters, skateboards, electric skateboards, gyroscooters, sigways, monocars and other similar devices), except for bicycles and wheelchairs [24];

23) A bicycle lane is either part of a public road or an independent road designed primarily for bicycle traffic. The movement of motor vehicles and animal-drawn carts on a bicycle lane is prohibited [25];

(24) Bicycle lane - a narrow (compared with ordinary automobile lanes) lane separated by a solid or dashed line of markings at the right (in countries with left-hand traffic - at the left) edge of the carriageway. Also, in cases where the carriageway has a special place for parking - parking lane or pocket for parallel parking, the bike lane may not be at the edge of the carriageway, but pass to the left of the parking spaces [26];

25) Parking - a technical term meaning the regular transfer of a mechanism, device, vehicle to a non-operational, stationary position in a safe place provided for this purpose.

\section{Empirical interpretation of the concepts:}

- costs of using a personal car: purchase of gasoline; payment of traffic fines; payment of transport tax; purchase of CTP (Compulsory Motor Third Party Liability Insurance) policy; depreciation costs; payment for inspection services; purchase of sets of winter and summer tires; payment for tire fitting services; payment for car wash services; payment for maintenance services; payment for paid parking in the city; purchase of relatively inexpensive consumables such as oil, anti-freeze agent, etc.

- costs of using public transport services: fare payments; costs associated with reaching the points of arrival of public transport; costs associated with the breakdown of public transport during the trip.

- quality of transport services: accessibility (remoteness of transport infrastructure from the place of residence of the population); safety; cost indicator; comfort (including the level of comfortable conditions when moving and waiting for the vehicle, as well as when boarding and disembarking); time criterion; information support level indicator; customer- 
oriented (politeness and friendliness of conductors in communication with passengers); environmental friendliness.

The sample and its rationale.

The general population in this study is the population of the city of Kazan.

The sample of this study includes 200 male and female residents of the city of Kazan, aged 16 to 71 years.

When determining the probability group of the sample population, we used solid sampling.

When conducting the survey we will use the «snowball» method (person-to-person).

Description of information collection methods and techniques and their rationale.

1) Questionnaire survey - this method of collecting information allows you to find out the opinion about the organization of urban transport infrastructure in a wide range of the population.

2) Content analysis is a special, rather strict and formalized method of qualitativequantitative analysis of various materials (documents, articles, etc.).

Applied methodological tools.

Empirical data in the study will be collected using:

1) a questionnaire;

2) information materials for content analysis.

We will conduct a small study, the purpose of which will be to calculate and compare the approximate costs in cash equivalent, which are made in 1 year by a hypothetical resident of Kazan when using a personal car to move around the city and when he uses the services of public transport for the same purposes.

In Kazan, the model rating of new cars sold in 2019 is headed by Kia Rio with 700 units sold. Next are Lada Granta with 563 cars, Lada Vesta with 535 cars. Hyundai Solaris is also generally popular across the country. These cars belong to the category of budget cars.

Let's calculate how much it costs approximately to own an inexpensive car for a resident of Kazan, who needs to get to and from his workplace every day by his Hyundai Solaris. Since this car model has an automatic gearbox and a 1.6 liter engine that consumes 9,3 liters per 100 kilometers in the city cycle, the citizen of Kazan from our study will need to buy gasoline with an octane number not lower than 92 to move around the city in his car. Suppose our driver chooses a medium-quality fuel, AI-95, a liter of which in the territory of Kazan at the moment costs on average 46 rubles.

Let's assume that our Kazanian works in some building on Kremlin Street, and lives near the metro station Prospekt Pobedy. This is 10 kilometers one way. He already does at least $20 \mathrm{~km}$ a day. Taking into account various other trips, traffic jams, stores, cafes, etc., this distance easily adds up to $30 \mathrm{~km}$ a day. During Sunday - his day off - our Kazanian is at home, driving his car $0 \mathrm{~km}$, and on Saturday or Friday night he goes to the cottage / out of town / for groceries. So let the car travels about $50 \mathrm{~km}$ over the weekend. Total we get about $200 \mathrm{~km}$ per week.

There are 52 weeks in the year, that is, for the year the mileage of the car will be 10400 $\mathrm{km}$ - which is 104 times $100 \mathrm{~km}$. Thus, for the year the car in the urban cycle will spend at least $104 * 9,3=967,2$ liters of gasoline, which will cost its owner in 44500 rubles.

Now let's turn to other items of expenditure.

Let's assume that our Kazan citizen has violated traffic rules several times during the year. Let's take the conditional amount of 3000 rubles for the year that the car owner spent on fines.

Vehicle tax on his Hyundai Solaris with $123 \mathrm{hp}$ will be 3500 rubles. Policy CTP (Compulsory Motor Third Party Liability Insurance) will cost the owner at least 10000 rubles a year. 
Depreciation on our Kazan resident's Hyundai Solaris, according to an analysis of the used car market, is around 65,000 rubles a year.

We assumed that the Kazaner has a new car, so the cost of technical inspection and a new set of summer tires can be neglected. But you will still have to buy winter tires for at least 12,000 rubles. Maximum three years of use it will have to change, that is, per year the cost will be 4000 rubles.

Tire fitting (twice a year) and tire repair in case of a puncture will cost 5000 rubles per year for a citizen of Kazan. You can add the cost of car washing. Complex car wash in Kazan costs from 500 rubles, that is, a year will go at least 6000 rubles.

Hyundai Solaris maintenance costs an average of about 10,000 rubles a year.

Accidents, breakdowns, traffic jams (and fuel overruns), and inexpensive consumables such as oil and antifreeze, we do not take into account due to the complexity of these calculations.

Let us calculate the total cost of our Kazan citizen for the maintenance and use of the car: $44500+3000+3500+10000+65000+4000+6000+10000=146000$ rubles annually.

It turns out that the owner of a new economy-class car that does not get into traffic accidents, does not break down, does not break down, and almost does not stand in traffic jams, spends at least 146,000 rubles a year in Kazan, or more than 12000 per month. In practice, however, there is a probability that the annual amount is likely to exceed 150,000 rubles.

Paid parking immediately dramatically increases the cost of owning a car. Parking at our hypothetical Kazan resident's workplace near Kremlin Street would cost him 300 rubles per day. That's 1500 rubles per week, or 78000 for the year.

Let's imagine that the same driver spends money not on his car, but on the use of public transport and cab services.

Two trips to and from work by subway would cost 60 rubles per day, 300 rubles per week, or 15,600 rubles per year. Let's assume that on weekends or sometimes on weekdays our Kazan citizen uses a cab to get to the store or to work if he is late. The average price of a cab ride in Kazan now is 150 rubles. If our Kazan citizen orders a cab for a year 104 times (twice a week), it will cost him 15600 rubles a year. Let's also imagine that sometimes on weekends our Kazaner uses the bus or the trolleybus, to get somewhere. You could take a round trip every two weeks. That is 120 rubles per month, or 6240 rubles per year.

Let's calculate the total cost of using public transport for our Kazan citizen: $15600+15600+6240=37440$ rubles per year. Assuming that our Kazan citizen will order a cab more often or use a carshare, the amount of expenses will increase to 50000 rubles per year.

So, our study found that a Kazan citizen using a relatively inexpensive personal car to move around the city for 1 year spends 146000 rubles, and when resorting to the services of public transport (including cabs) - 37440 rubles a year. The difference in amounts is enormous.

Thus, a personal car is an additional expense, and quite substantial. Using public transport in Kazan is almost three times cheaper than using a car.

\section{Results}

Conducting a survey on the rejection of personal cars as a means of transport in the city among residents of Kazan, we were able to get answers from 200 respondents. To begin 
with, we will conduct a detailed analysis of the received answers to each question of the questionnaire separately.

The target audience of our survey is represented by people of different age groups. The number of representatives of each group is shown in Figure 1.

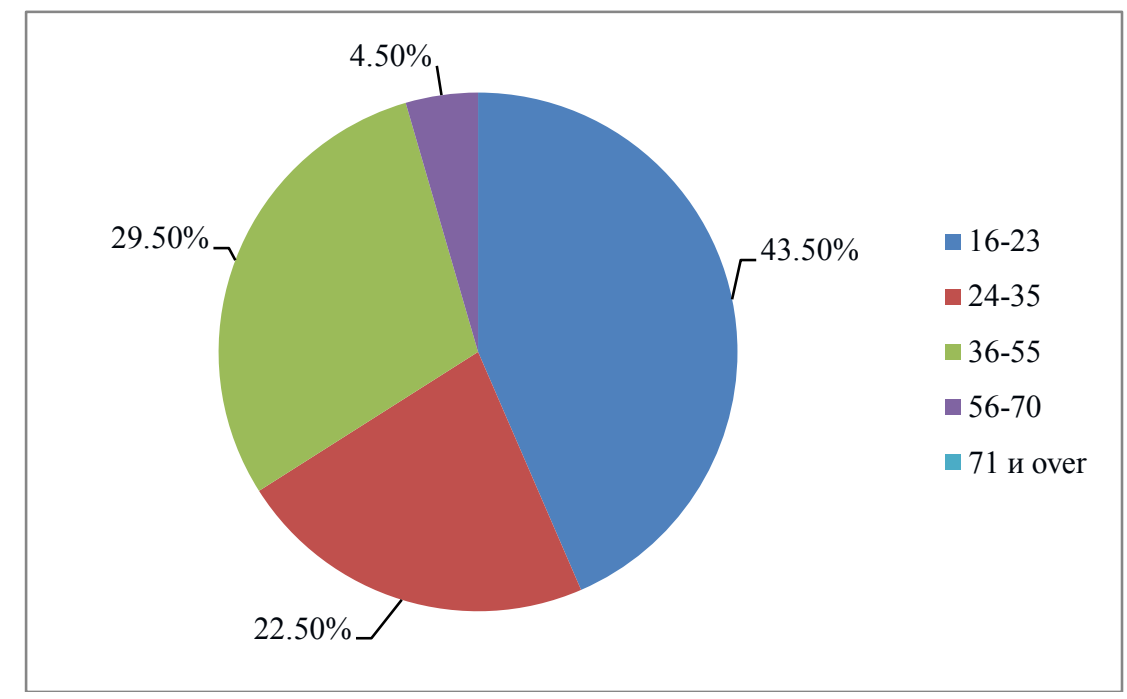

Fig. 1. Age groups participating in the survey.

The majority of respondents belonged to the 16-23 age group (43.5\% of the total number), followed by the $36-55$ age group (29.5\% of the total number), then $24-35(22.5 \%$ of the total number). Also, a small number of answers was received from representatives of the age group 56-70 (4.5\% of the total number). Unfortunately, representatives of the age group 71 and over did not participate in our survey. Thus, representatives of different age groups participated in our survey, but young and middle-aged people prevailed.

In the first question we tried to find out if the respondents have a personal car or if they are considering buying one in the next few years. According to the results of the survey, the answers to this question were distributed as follows:

Of the total number of respondents, $31.5 \%$ have a personal car; $32.5 \%$ do not have a personal car but intend to purchase one in the next few years; $24 \%$ do not have a personal car but do not rule out the possibility of purchasing one in the future and only $12 \%$ do not have a personal car and will not purchase one. Since only 24 people out of 200 surveyed do not have a personal car and do not intend to purchase one, for the vast majority a personal car is a necessary attribute for living in the city. This means that, at this point, people are not at all ready for the idea of living in the city without a personal car. In implementing the results of the survey, the most difficult work should be done with those who chose the first or second answer ( $64 \%$ of the total number). In order for these categories of citizens to refuse to use or buy a private car, it is necessary to provide them with an alternative that is better in all aspects. People who chose the third option (24\% of the total number) can be categorized as «undecided». With them the task is a little easier - it is necessary to give them a way to move around the city, making it fast, convenient, comfortable and inexpensive. And then these people will not buy a personal car in the future. The most loyal to our idea category is only $12 \%$ of the total number of respondents. According to the results of the answers it is possible to reveal not very favorable tendencies for the idea of giving up a personal car and switching to moving around the city only by public transport. 
In the second question we tried to find out under what conditions people would refuse to use a personal car or to buy one. It was a multiple-choice question. According to the results of the survey, the answers to this question were distributed as follows (Fig. 2).

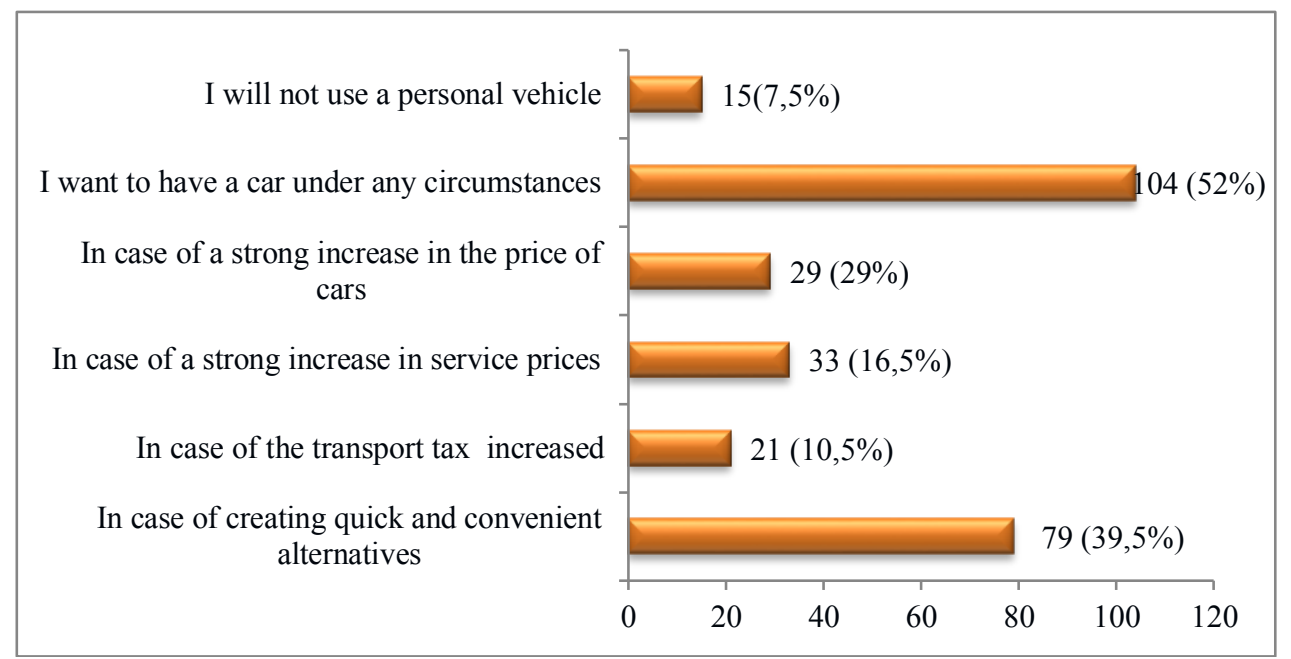

Fig. 2. Conditions of refusal to use a personal car or to buy one.

From the data presented above (Fig. 2) it can be noted that people who will not use a car under any conditions are only $7.5 \%$ of the total number. This is the most loyal category of respondents, as they do not need any action from the outside to refuse to move around the city in a personal car. It can also be noted from the answers that financial measures of influence on the use of a personal car (increase in prices for cars, increase in prices for car maintenance, increase in transport tax) in general are not very popular among respondents and, therefore, are not good reasons for refusal to use a personal car. In other words, there is a great risk of not transferring people en masse to public transport and not increasing its popularity, affecting the price component from the use of a personal car. Thus, the measures mentioned above are currently ineffective. The majority of respondents $(52 \%$ of the total) want to own any car under any circumstances. With this category of people will have to work most actively in the process of implementation of the idea of refusal to use a personal car in the city, as it will be difficult to change their minds. But the situation is not so bad, because $39,5 \%$ of the total number of respondents are ready to refuse using a personal car or buying one when they create fast and convenient alternative ways of moving around the city. This category of people should be emphasized, as they are relatively loyal to the idea of not using a personal car in the city, they just need to give them the opportunity to use alternative ways of getting around the city. These results are not very optimistic, but they give real hope for the realization of the idea of not using a personal car when creating alternative means of transportation in the city.

In the third question, we tried to find out how the respondents estimated the intensity of their commute in the city (Fig. 3). 


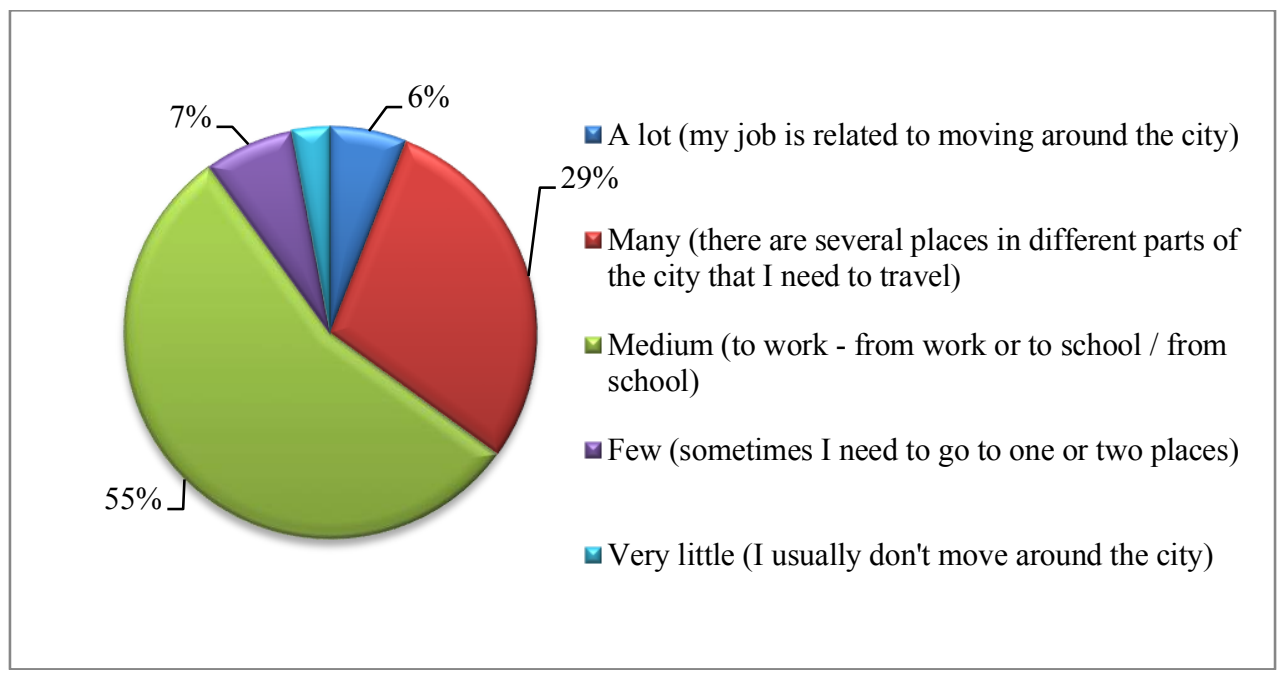

Fig. 3. Intensity of respondents' movement around the city.

The number of people who chose the first and the second answers is $35,5 \%$. This category of people moves around the city a lot or a lot per day (for various reasons: personal, work, family, forced), so it is hardly possible to transfer them to public transport and disincline them from using a personal car. However, the remaining people who chose the third, fourth and fifth answer options (64.5\% of the total number), whose movements around the city are not so frequent, it is quite possible to disincline them from using a personal car and transfer them only to public transport or other means of individual mobility on a permanent basis. These results are quite positive, the information obtained from the answers confirms the possibility of people to refuse to use a personal car.

In the fourth question we asked how often Kazan residents use public transportation to get around the city.

The number of people who use public transportation often $(43 \%)$ or very often $(6.5 \%)$ is $49.5 \%$ of the total number of respondents. These results are very positive, because at the moment public transport is really in demand and relevant for daily travel for almost half of the total number of respondents. And it is likely that this category is already ready to give up using private transport or intend to buy it in the future if the current state of infrastructure and travel routes is maintained. People who chose the third option «Sometimes (once every few days)» $(25.5 \%)$ represent the category of «undecided». It is most likely that they choose between the possibility of moving by public transport and a private car. Since they are not categorical about moving by public transport, it is necessary to carry out work aimed at ensuring that they choose it for their movements all the time. The most «dangerous» category for us are the people who chose the fourth option - «Rarely (once every few weeks)» and the fifth option - «Never» response (25\% of the total number). This category very rarely or not at all uses public transportation. There are quite a few of them (a quarter of the total number of respondents), so this point cannot be ignored. Before to disincline them from using a private car, it is necessary to find out the reasons why they do not use public transport at the moment. And, based on this, to take appropriate measures (it may be necessary to create new routes of public transport). Also, based on the results of the answers to this question, it can be concluded that public transport in Kazan is now quite relevant and in demand among the population.

In the fifth question we found out, what means of mobility in addition to a personal car and public transport (bus, trolley bus, streetcar, metro) are used by Kazan citizens to move around the city. According to the results of the survey, answers to this question were 
distributed as follows: $179(89.5 \%)$ cabs, 21 (10.5\%) bicycles, scooters - 4 (2\%), other personal means of mobility - $21(10.5 \%)$.

We can conclude that the most popular among respondents is the cab (179 people out of 200 respondents have chosen this answer). It is worth noting that, despite existing misconceptions, cabs belong to public transport. Cabs are capable of carrying several passengers, in addition, they can drive in a dedicated lane on the roads. The fact that cabs are actively used is quite positive, as it demonstrates that almost all respondents use and are willing to use cabs for some travel. Certainly, the use of cabs is more positive for the city than the use of a private car. Also based on the answers, we can observe that such means of transportation as: bicycle, scooter, other means of personal mobility (rollers, skateboards, gyro scooters, segways, mono wheels, etc.) are not popular among citizens of Kazan. There can be several reasons for this: lack of environment and infrastructure for movement and use of these means of transportation; peculiarities of public consciousness, in which these means of transportation are perceived either as seasonal or as recreational. Measures must be taken to combat these causes. First of all, it is necessary to create conditions for the use of these means of transportation - to build more pedestrian zones and bicycle lanes in the city; to increase the number of available rental outlets for these means of transportation; to pose to society the idea of active use of these means of transportation.

In the sixth question we tried to find out what kind of transport, except a personal car, Kazan citizens use most often.

It can be noted that at the moment the most popular among Kazan citizens are buses, metro and cabs (105, 125 and 105 votes out of 200, respectively). Kazan residents are quite satisfied with the listed modes of public transport, and they quite often choose these modes for their movements around the city. However the answers «trolleybus» and «streetcar» did not receive so many votes ( 38 and 27 respectively), based on which we can conclude that these means of public transport should be developed, new routes should be launched, the number of rolling stocks on current routes should be increased.

In the seventh question we evaluated the satisfaction of the population of the city of Kazan with the current state of urban public transport in terms of various criteria (Table 1).

Table 1. Satisfaction of the population of the city of Kazan with the current state of urban public transport.

\begin{tabular}{|c|c|c|}
\hline Questions & Answer & Distribution \\
\hline $\begin{array}{l}7 . \quad \text { Rate your } \\
\text { satisfaction with } \\
\text { public transport (bus, } \\
\text { trolleybus, tram and } \\
\text { metro) according to } \\
\text { the following } \\
\text { criteria. }\end{array}$ & $\begin{array}{l}\text { Criteria: } \\
\text { 1. Comfort of movement } \\
\text { 2. Speed of movement } \\
\text { 3. The price of travel } \\
\text { 4. Condition of transport } \\
\text { 5. Professional suitability } \\
\text { of conductors and drivers } \\
\text { 6. Availability (possibility) } \\
\text { of use } \\
\text { Evaluation of criteria: } \\
\text { a) Satisfied. } \\
\text { b) Rather satisfied } \\
\text { c) More likely dissatisfied } \\
\text { d) Displeased }\end{array}$ & $\begin{array}{l}\text { Comfort of movement: } \\
\text { a. } 58 / 29 \% \text {; b. } 84 / 42 \% \text {; c. } 38 / 19 \% \text {; } \\
\text { d. } 20 / 10 \% \\
\text { Movement speed: } \\
\text { a. } 60 / 30 \% \text {; b. } 81 / 40.5 \% \text {; c. } 47 \text { / } \\
23.5 \% \text {; d. } 12 / 6 \% \\
\text { Fare price: } \\
\text { a. } 61 / 30.5 \% \text {; b. } 74 / 37 \% \text {; c. } 40 / 20 \% \text {; } \\
\text { d. } 25 / 12.5 \% \\
\text { Transport status } \\
\text { a. } 57 / 28.5 \% \text {; b. } 105 / 52.5 \% \text {; c. } 31 / \\
15.5 \% \text {; } 7 / 3.5 \% \\
\text { Aptitude of conductors and drivers: } \\
\text { a. } 48 / 24 \% \text {; b. } 96 / 48 \% \text {; c. } 44 / 22 \% \text {; } \\
\text { d. } 12 / 6 \% \\
\text { Availability of use } \\
\text { a. } 83 / 41.5 \% \text {; b. } 75 \text { / } 37.5 \% \text {; c. } \\
40 / 20 \% \text {; d. } 2 / 1 \%\end{array}$ \\
\hline
\end{tabular}

First of all, it is worth noting that within each criterion, there are more respondents who are satisfied or rather satisfied with public transport than respondents who are rather 
dissatisfied or dissatisfied with it. For the first 5 criteria for assessing the condition of public transport in Kazan, respondents indicated that they were rather satisfied with the comfort of travel, speed of travel, fare, the condition of transport and professionalism of conductors and drivers. For the criterion of accessibility of use, most respondents indicated a rating of «atisfied», and then by the number of voters is followed by the evaluation of the criterion «rather satisfied».

In the eighth question we tried to find out the opinion of Kazan citizens about their willingness to use only public transport to move around the city.

In general respondents gave preference to two answers. Thus, on the one hand, 90 people ( $45 \%$ of respondents) answered that they are ready to use only public transport, but they will also use cabs. On the other hand, 88 people (44\%) responded that they would only use a private car for all movements around the city. The remaining three answer choices combined accounted for only 22 people. 14 respondents $(7 \%)$ indicated that they would be willing to use public transportation, but they would also rent bikes/scooters and order cabs. Another 6 people $(3 \%)$ responded that public transportation meets all of their needs, and only two people (1\%) indicated that they were willing to use only public transportation, but would not rule out using scooters/bicycles to get around town. As a result, the survey for this question resulted in a rather contradictory situation, with one half of respondents willing to completely switch to public transportation and cabs, and the other half willing to use only a personal car if available.

In the ninth question we sought to find out what would increase the attractiveness of public transport (bus, trolleybus, streetcar, metro) in the eyes of respondents and contribute to its choice to move around the city (it was a multiple-choice question) (Fig. 4).

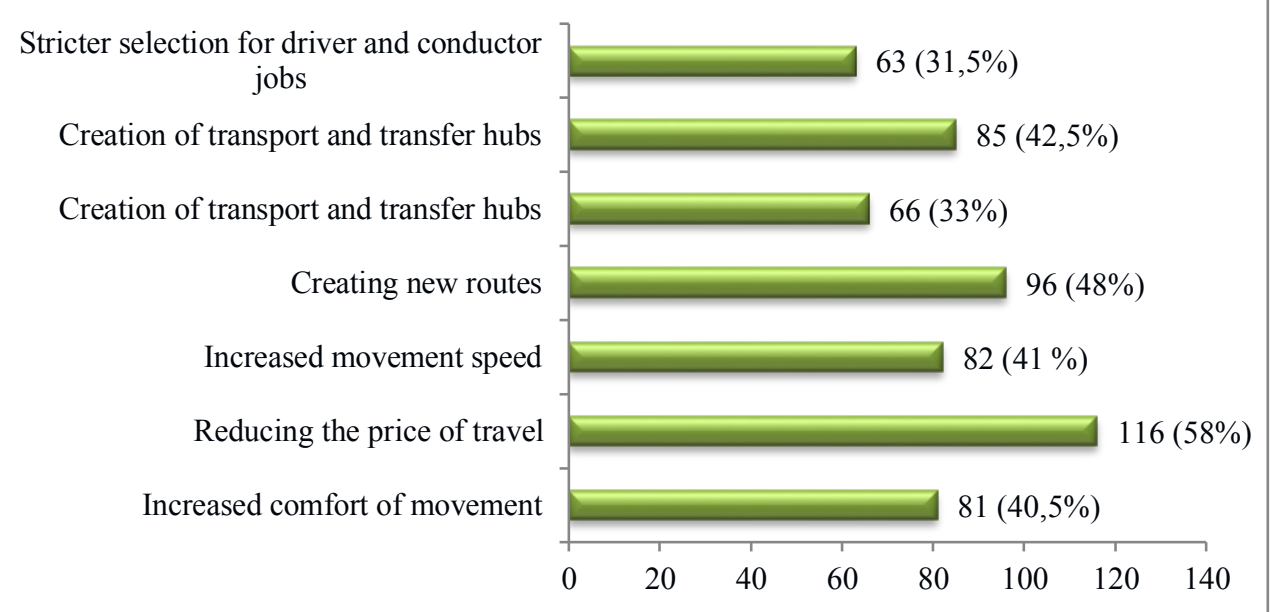

Fig. 4. Reasons for increasing the attractiveness of public transport (bus, trolleybus, streetcar, metro) in the eyes of respondents and their choice to move around the city.

In general, respondents chose different factors and sides of the development of public transport in the survey. For the majority of respondents, the price of a trip and the number of routes were most important when switching to public transportation altogether.

The purpose of the tenth question was to find out under what conditions respondents would use a bicycle or scooter (their own or rented) more often to get around the city.

The vast majority of respondents (124 people, $62 \%$ ) said that they would use a bicycle or scooter more often to get around town if they could not use other means of transportation. 72 respondents (36\%) would begin to use scooters and bicycles more often if there were more pedestrian zones and bicycle lanes; 42 respondents $(21 \%)$ would start 
using their bicycle or scooter after buying one; 36 respondents (18\%) would start using it more often if the rental price decreased; and 27 respondents $(13.5 \%)$ would use it more if there were more rental locations.

The eleventh question was to find out how much time, on average, respondents stand in traffic jams in the city per day.

Most respondents (89 people, 44.5\%) said they did not stand in traffic jams. Also a significant number of people (81 respondents, $40.5 \%$ ) responded that they stand in traffic jams for less than 1 hour. Only 18 respondents $(9 \%)$ stated that they stand in traffic jams for less than 2 hours. 8 people $(4 \%)$ stand in traffic jams for more than 2 hours, and 4 respondents $(2 \%)$ stand in traffic jams for more than 4 hours on average.

In the twelfth question we tried to find out how the respondents assessed the effectiveness of the proposed measures to reduce the number of traffic jams (Table 2).

Table 2. Effectiveness of proposed measures to reduce traffic congestion.

\begin{tabular}{|c|c|c|}
\hline Question & Answer & Distribution \\
\hline $\begin{array}{l}\text { Evaluate the } \\
\text { effectiveness } \\
\text { of the } \\
\text { following } \\
\text { measures to } \\
\text { reduce traffic } \\
\text { congestion. }\end{array}$ & $\begin{array}{l}\text { Criteria: } \\
\text { 1. Development of public transport } \\
\text { 2. Allocation of a separate lane on } \\
\text { roads for public transport and cabs } \\
\text { 3. Increasing the number of scooter } \\
\text { and bicycle rentals } \\
\text { 4. Increasing the number of } \\
\text { pedestrian roads } \\
5 . \quad \text { Increase in the number of } \\
\text { bicycle lanes and bike lanes } \\
\text { 6. Expansion of existing highways } \\
\text { 7. Construction of new highways } \\
\text { Evaluation of criteria: } \\
\text { a. Effective } \\
\text { b. Rather effective } \\
\text { c. Rather ineffective } \\
\text { d. Ineffective }\end{array}$ & $\begin{array}{l}\text { Criteria: } \\
\text { Development of public transportation: } \\
\text { a. } 59 / 29,5 \% \text {; b. } 62 / 31 \% \text {; c. } 36 / 18 \% \text {; d. } \\
43 / 21,5 \% \\
\text { Allocating a separate lane on roads for } \\
\text { public transportation and cab traffic: } \\
\text { a. } 69 / 34,5 \% \text {; b. } 55 / 27,5 \% \text {; c. } 42 / 21 \% \text {; d. } \\
34 / 17 \% \\
\text { Increase in the number of scooter and } \\
\text { bicycle rentals: } \\
\text { a. } 21 / 10,5 \% \text {; b. } 63 / 31,5 \% \text {; c. } 63 / 31,5 \% \text {;d. } \\
53 / 26,5 \% \\
\text { Increase in the number of pedestrian } \\
\text { roads: } \\
\text { a. } 27 / 13,5 \% \text {; b. } 54 / 27 \% \text {; c. } 58 / 29 \% \text {; d. } \\
61 / 30,5 \% \\
\text { Increase in the number of bicycle lanes } \\
\text { and bike lanes: } \\
\text { a. } 30 / 15 \% \text {; b. } 69 / 34,5 \% \text {;c. } 52 / 26 \% \text {;d. } \\
49 / 24,5 \% \\
\text { Expansion of existing roadways: } \\
\text { a. } 109 / 54,5 \% \text {; b. } 76 / 38 \% ; \text {;. } 7 / 3,5 \% \text {;d. } \\
8 / 4 \% \\
\text { Construction of new highways: } \\
\text { a. } 103 / 51,5 \% \text {; b. } 79 / 39,5 \% ; \text { c. } 9 / 4,5 \% \text {;d. } \\
9 / 4,5 \%\end{array}$ \\
\hline
\end{tabular}

As a result, in general, respondents consider the development of public transport, the allocation of a separate lane on the roads for public transport and cabs to be effective measures to eliminate traffic jams. Increasing the number of scooter and bicycle rental stations, increasing the number of pedestrian roads and increasing the number of bicycle lanes and white lanes are not considered by many respondents as the most effective measures. The vast majority of respondents considered the expansion of existing highways and the construction of new highways to be effective measures in combating traffic congestion.

In the thirteenth question, we tried to find out from respondents what measures aimed at reducing personal car use the city authorities should take.

The majority of respondents chose two answers out of six: 121 people $(60,5 \%)$ responded that authorities should create convenient and fast alternative ways to get around, 
and 95 people $(47,5 \%)$ responded that authorities do not need to influence personal car use. An equal number of respondents - $23(11,5 \%)$ - chose the following answers - to introduce paid parking in the center of the city and to introduce paid parking everywhere. Such measure as a large tax on personal cars was chosen by 17 people $(8,5 \%)$. And narrowing of the roads and decrease in the number of lanes was chosen by 11 people $(5,5 \%)$. As a result, a contradiction arose again within the framework of this question. On the one hand, people think that the authorities should influence the reduction of personal car use by creating alternatives. On the other hand, quite a few respondents also said that the authorities do not need to reduce the use of the private car.

In question 14, we decided to identify the main expectations of the citizens of the possible decrease in the use of private cars by motorists and the transition of the majority of the population to public transport. It is worth noting that the respondent could choose several answer options, which means that the statements that scored a low percentage of votes appear to be wrong to most respondents.

The following statements were presented to respondents for analysis:

1. Reducing the use of a personal car will increase the attractiveness of the city;

2. Reducing the use of the personal car will make it more difficult to get around the city;

3. Developing public transportation will make the city more livable;

4. eliminating the use of a personal car will reduce the cost of getting around the city for residents;

5. Refusal to use a personal car will promote healthy lifestyles among the population;

6. Frequent use of public transportation will negatively affect the emotional health of the population;

7. Climate has a strong impact on the ability to use personal mobility (bicycles, scooters)

The results of the survey showed the following results: the highest percentage of votes was obtained in the statements: 6 - 90 (45\%), 3 - 85 (42,5\%), 2 - 83 (41,5\%), which indicates a rather interesting trend: Kazan residents understand the importance and need to develop public transportation, but are not ready to switch to it and give up using a personal car, citing the more difficult movement around the city and the possible negative impact on emotional health and climatic conditions. In addition, most residents do not believe that reducing the use of a personal vehicle will increase the attractiveness of the city and reduce the cost of getting around the city (survey results: options $1-23(11,5 \%)$ and $4-44(22 \%)$ ).

Based on the results of this question, we can conclude that residents support the initiative to develop public transport, but in this case they think not so much about replacing the personal car by public transport, but rather about improving the comfort of moving around the city of children, persons without a driver's license and/or car, etc.

The fifteenth question was aimed at determining the gender structure of the respondents:

Thus, $51 \%$ of males and $49 \%$ of females participated in the survey, indicating that both genders were equally interested in the topic.

Using the passport question in our questionnaire to determine information about the marital status of respondents, we found that a relative majority $(37,5 \%)$ of respondents are currently unmarried:

Slightly less than a quarter $(24,5 \%)$ of respondents were married and had children. Equal shares (19\% each) of the responses were "married" and "in a relationship. Thus, we concluded that we were able to attract citizens of Kazan - representatives of different categories depending on their marital status - to our survey, which is a favorable factor for ensuring the representativeness of our survey. 
The type of a person's main activity is a factor that largely determines the pace of his or her life and the extent to which he or she moves around the city, and therefore his or her need for mobility, so question 18 of the questionnaire was devoted to this very aspect:

Unemployed residents in our survey participated only 8 people or $4 \%$. One person was a representative of pensioners of Kazan. But the rest of our sample is either employed (48,5\% - almost half of those surveyed), or students (33\% or one-third of those surveyed), or employed students (14\%).

Since one of our hypotheses is based on the assumption that there is a connection between a person's higher education and their understanding of the importance of public transport measures in the city, we needed to obtain information about the current level of education of the Kazan residents who took our survey, which we did in question nineteenth. Thus, it was revealed that people with higher education (be it specialist, bachelor or master degree) among our respondents were a relative majority, almost equal to half of those surveyed $(44,5 \%)$. The number of respondents with incomplete higher education was also quite large (28\%) - more than a quarter of all respondents. Taking into account the fact that $6 \%$ of respondents have degrees or titles, we can say that only $78,5 \%$ of respondents are connected in one way or another with higher education. We were able to involve only people with secondary general education in our poll only in the amount of $10,5 \%$, and 9,5 $\%$ of Kazan citizens with secondary professional education. Only 3 people out of 200, involved in our survey, were representatives of Kazan citizens with incomplete secondary vocational education:

One of the hypotheses formulated when writing the methodological part of this research, is of the nature of the assumption of presence of dependence of readiness of inhabitants to refuse to use the personal car, as a means of transport in the city, on a level of their incomes. Therefore, we could not help but include in our questionnaire a question about the financial situation of the respondents, during which it was found out:

Approximately equal shares of respondents (28\% each) came from people whose incomes are relatively average: people who have enough money at their disposal for food and clothing but find it difficult to buy large household appliances and residents whose incomes, in their own opinion, are sufficient to buy large household appliances but not to buy a personal car. $20 \%$ of respondents have money for the immediate purchase of a personal car, and less than $10 \%$ of respondents $(7,5 \%)$ consider that they do not have any financial difficulties. The group of people with quite low income included 30 respondents $(15 \%)$ for whom it is difficult to buy clothes and 2 people $(1 \%)$ who cannot satisfy all their needs for food.

\section{Discussion}

Let us formulate a number of research hypotheses, the confirmation or non-confirmation of which we will check as part of the analysis of the results of our questionnaire survey by cross-grouping:

1. The majority of respondents over the age of 24 either have a personal vehicle or intend to purchase one in the near future.

2. There are more male respondents who necessarily want to own a personal car compared to the female respondents.

3. The majority of respondents, who have a financial situation lower than that in which it would not be difficult to purchase a personal car, either already have a personal car or intend to purchase a personal car within a few years.

4. Young people in the 16-23 age group are more likely to routinely use public transportation as their primary means of getting around town. 
5. Young people in the 16-35 age group use personal mobility devices (bicycle, scooter, other personal mobility devices) more often than middle-aged and elderly people, in addition to their personal car and public transportation.

6. With the apparent ineffectiveness of expanding existing roads by adding lanes on them as a means of combating traffic congestion, respondents with secondary education, who would rate this measure to combat traffic congestion in the city as effective or rather effective, would be more than the same respondents with higher education.

7. The majority of respondents who own or intend to purchase a personal car within a few years are against enforcement measures by the authorities to reduce the use of the personal car as the primary means of transportation in the city.

8. Family people are more likely to choose a personal car as the only possible way to get around town.

9. People without higher education do not understand the importance of developing public transportation in the city as a measure to reduce traffic congestion.

10. The level of income of respondents influences the willingness of residents to refuse the use of private cars to move around the city.

11. Women are more loyal to the possibility of giving up their own cars. 12.

12. Such categories of respondents as students and working students use public transport services to move around the city more often than others.

Hypothesis 1: The majority of respondents over the age of 24 either have a personal car or intend to buy one in the near future.

Let us check if our first hypothesis is confirmed with the help of a cross-grouping (bivariate table) within the framework of the conducted survey (Table 3).

Table 3. Two-dimensional table for testing hypothesis 1 .

\begin{tabular}{|c|c|c|c|}
\hline \multirow[b]{2}{*}{$\begin{array}{l}\text { 16. Specify } \\
\text { your age } \\
\text { group. }\end{array}$} & \multicolumn{2}{|c|}{$\begin{array}{l}\text { 1. Do you own a personal vehicle or do you intend to } \\
\text { purchase one in the next few years? }\end{array}$} & \multirow[b]{2}{*}{ Total } \\
\hline & $\begin{array}{l}\text { I have a car / I do not have a } \\
\text { car. but I intend to buy it in } \\
\text { the next few years }\end{array}$ & $\begin{array}{l}\text { No car. but future } \\
\text { acquisition is not } \\
\text { excluded / No car. no } \\
\text { plans to buy it }\end{array}$ & \\
\hline $16-23$ & $37(18.5 \%$ from 200$)$ & $50(25 \%)$ & $87(43.5 \%)$ \\
\hline $24-35$ & $38(19 \%)$ & $7(3.5 \%)$ & $45(22.5 \%)$ \\
\hline $\begin{array}{l}36-55 \\
56-70\end{array}$ & $46(23 \%)$ & $13(6.5 \%)$ & $59(29.5 \%)$ \\
\hline $56-70$ & $7(3.5 \%)$ & $2(2 \%)$ & $9(4.5 \%)$ \\
\hline $\begin{array}{l}71 \text { and } \\
\text { more }\end{array}$ & 0 & 0 & 0 \\
\hline $\begin{array}{c}\text { Total over } \\
24\end{array}$ & $\begin{array}{l}91(45.5 \% \text { from } 200 / 80.5 \% \\
\text { from } 113)\end{array}$ & $\begin{array}{l}22(11 \% \text { from } 200 / 9.7 \% \\
\text { from } 113)\end{array}$ & $\begin{array}{l}113(56.5 \% \\
\text { from } 200 / \\
100 \%)\end{array}$ \\
\hline Total & $128(65 \%)$ & $72(35 \%)$ & $200(100 \%)$ \\
\hline
\end{tabular}

The results of cross-grouping showed that 200 answers were given to questions 1 and 16 , i.e. exactly the same number of people who took the survey (both questions were with a single choice of answer options).

Thus, a bivariate table of the first hypothesis shows us that according to the results of the survey the hypothesis is confirmed - the majority of respondents over 24 years old (91, or $80.5 \%$ of all respondents over 24 ) already have a car or are going to buy one soon. This means that the majority of middle-aged and older Kazan citizens have a car or are going to have one in the near future.

Hypothesis 2. There are more male respondents that would definitely like to own a personal car as compared to female respondents.

Hypothesis 11. Women are more loyal to the possibility of not having a personal car. 
Let's check with the help of cross-grouping (bivariate table) whether our second and eleventh hypotheses were confirmed within the framework of the conducted questionnaire (Table 4).

Table 4. Two-dimensional table for testing hypotheses 2 and 11.

\begin{tabular}{|c|c|c|c|}
\hline \multirow[b]{2}{*}{$\begin{array}{c}\text { Specify } \\
\text { your } \\
\text { gender. }\end{array}$} & \multicolumn{2}{|c|}{$\begin{array}{l}\text { 2. Under what conditions would you refuse to use a personal } \\
\text { car (from its purchase)? }\end{array}$} & \multirow[b]{2}{*}{ Overall } \\
\hline & $\begin{array}{l}\text { I want to } \\
\text { have a car } \\
\text { anyway }\end{array}$ & $\begin{array}{l}\text { I will give up using a car under certain } \\
\text { circumstances (increase in car } \\
\text { prices/maintenance; increase in car taxes; } \\
\text { creation of alternative means of } \\
\text { transportation; unwillingness to have a car) }\end{array}$ & \\
\hline Male & $\begin{array}{c}51(25.5 \% \\
\text { from } 200 / \\
59.3 \% \text { from } \\
86)\end{array}$ & $51(25.5 \%)$ & $102(51 \%)$ \\
\hline Female & $\begin{array}{c}35(17.5 \% \\
\text { from } 200 / \\
40.7 \% \text { from } \\
86) \\
\end{array}$ & $63(31.5 \%)$ & $98(49 \%)$ \\
\hline Total & $\begin{array}{l}86(43 \% \text { from } \\
200 / 100 \%)\end{array}$ & $114(57 \%)$ & $\begin{array}{c}200 \\
(100 \%)\end{array}$ \\
\hline
\end{tabular}

The results of cross-grouping showed that 200 answers were given to questions 2 and 15 , i.e. exactly the same number of people who took the survey (question 2 was with multiple choice of answers, question 1 was with a single choice of answers).

Thus, the bivariate table shows us, that according to the results of the poll the second hypothesis is confirmed - the number of respondents who would like to have a private car is in any case higher among men (51 people), than among women (35 people). According to the results of the bivariate table, hypothesis number eleven was also confirmed, since the number of women who are ready, under certain conditions, to refuse using a private car (63 people) turned out to be greater than the number of men (51 people) who are ready to do the same.

At the same time it is important to note that in general among the respondents those who are ready to refuse to use a personal car under certain circumstances prevail $(57 \% \mathrm{vs}$. $43 \%)$.

Hypothesis 3. The majority of respondents who have a financial situation below that in which acquiring a personal car would not be difficult either already have a personal car or intend to acquire a personal car within a few years.

Let's check with cross-grouping (bivariate table) to see if our third hypothesis is confirmed by the questionnaire (Table 5).

Table 5. Two-dimensional table for testing hypothesis 3.

\begin{tabular}{|c|c|c|c|}
\hline \multirow{2}{*}{$\begin{array}{c}\text { 20. Indicate your financial } \\
\text { situation. }\end{array}$} & $\begin{array}{c}\text { 1. Do you own a personal vehicle or do you intend } \\
\text { to purchase one in the next few years? }\end{array}$ & \multirow{2}{*}{ Total } \\
\cline { 2 - 3 } & $\begin{array}{c}\text { I have a car / I do not } \\
\text { have a car. but I } \\
\text { intend to buy it in the } \\
\text { next few years }\end{array}$ & $\begin{array}{c}\text { No car. but future } \\
\text { acquisition is not } \\
\text { excluded / No car. no } \\
\text { plans to buy it }\end{array}$ & \\
\hline $\begin{array}{c}\text { Financial situation in one } \\
\text { way or another does not } \\
\text { allow the purchase of a } \\
\text { personal car }\end{array}$ & $\begin{array}{c}85(42.5 \% \text { from } 200 / \\
57.4 \% \text { from } 148)\end{array}$ & $63(31.5 \%$ from $200 /$ & $\begin{array}{c}148 \\
(74 \% \\
\text { from } 200 \\
/ 100 \%)\end{array}$ \\
\hline There is enough money to & $32(16 \%$ from 200$)$ & $8(4 \%)$ & $40(20 \%)$ \\
\hline
\end{tabular}




\begin{tabular}{|c|c|c|c|}
\hline $\begin{array}{c}\text { buy a personal car. but } \\
\text { buying real estate is } \\
\text { difficult }\end{array}$ & $8(4 \%)$ & $4(2 \%)$ & $12(6 \%)$ \\
\hline $\begin{array}{c}\text { There are no financial } \\
\text { difficulties. if necessary. it } \\
\text { is possible to buy real estate }\end{array}$ & $125(62.5 \%)$ & $75(37.5 \%)$ & $\begin{array}{c}200 \\
(100 \%)\end{array}$ \\
\hline Total &
\end{tabular}

The results of cross-grouping showed that 200 answers were given to questions 1 and 20 , i.e. exactly the same number of people who took the survey (both questions were with a single answer choice).

The first question was answered by 148 respondents (74\% of $200 / 100 \%)$ whose financial status in one way or another does not allow them to buy a personal car; 40 respondents $(20 \%$ of 200$)$ who have enough money to buy a personal car, but it would be difficult to buy real estate; 12 respondents $(6 \%$ of 200$)$ who have no financial difficulties.

Thus, the bivariate table for the second hypothesis shows us that according to the results of the survey the hypothesis is confirmed - the majority of respondents who have a financial situation below the one in which it would not be difficult to purchase a personal car, either already have a personal car or intend to purchase a personal car within a few years (85 respondents / 63 respondents).

It is important to note that, in general, those who either already have a car or intend to buy one within a few years $(62,5 \% / 37,5 \%)$ prevail among the respondents.

Hypothesis 4. Young people in the 16-23 age group are more likely to routinely use public transportation as their primary means of getting around town.

Let's check with cross-grouping to see if our fourth hypothesis is confirmed in this questionnaire (Table 6).

Table 6. Two-dimensional table for testing hypothesis 4.

\begin{tabular}{|c|c|c|c|}
\hline \multirow[b]{2}{*}{$\begin{array}{l}\text { 16.Specify } \\
\text { your age } \\
\text { category }\end{array}$} & \multicolumn{3}{|c|}{ 4. How often do you use public transportation to get around the city? } \\
\hline & $\begin{array}{c}\text { Very often (more than } \\
3 \text { times a day) / Often } \\
\text { (1-2 times a day) }\end{array}$ & $\begin{array}{l}\text { Sometimes (once every } \\
\text { few days) / Rarely (once } \\
\text { every few weeks) / Never }\end{array}$ & Total \\
\hline $16-23$ & $\begin{array}{c}61(30.5 \% \text { from } 200 / \\
70.9 \% \text { from } 86)\end{array}$ & $\begin{array}{c}25(12.5 \% \text { from } 200 / 29.1 \\
\% \text { from } 86)\end{array}$ & $\begin{array}{c}86(43 \% \text { from } 200 / \\
100 \%)\end{array}$ \\
\hline $24-35$ & $21(10.5 \%)$ & $24(12 \%)$ & $45(22.5 \%)$ \\
\hline $36-55$ & $15(7.5 \%)$ & $44(22 \%)$ & $59(29.5 \%)$ \\
\hline $56-70$ & $1(0.5 \%)$ & $9(4.5 \%)$ & $10(5 \%)$ \\
\hline Total & $98(49 \%)$ & $102(51 \%)$ & $200(100 \%)$ \\
\hline
\end{tabular}

Both questions were with a single answer choice.

Thus, the fourth hypothesis was confirmed - young people from the age group 16-23 are more inclined to the daily use of public transport as the main means of transportation in the city $(61 / 25)$.

In general, among all respondents, the part that sometimes or rarely uses public transport to get around the city prevails (49\% / 51\%).

Hypothesis 5. Young people in the 16-35 age group use personal mobility aids (bicycle, scooter, and other personal mobility aids) more frequently than middle-aged and elderly people, in addition to their personal car and public transportation.

Let us check with cross-grouping (two-dimensional table) whether our fifth hypothesis is confirmed by the questionnaire (Table 7). 
Table 7. Two-dimensional table for testing hypothesis 5 .

\begin{tabular}{|c|c|c|c|}
\hline \multirow{2}{*}{$\begin{array}{c}\text { 16.Specify } \\
\text { your age } \\
\text { category }\end{array}$} & \multicolumn{3}{|c|}{$\begin{array}{c}\text { 5. What means of mobility do you use to get around the city. in addition to } \\
\text { your personal car and public transport (bus. trolleybus. tram. metro)? }\end{array}$} \\
\cline { 2 - 4 } & Taxi & $\begin{array}{c}\text { Bicycle / Scooter / Other means of } \\
\text { personal mobility }\end{array}$ & Total \\
\hline $\begin{array}{c}16-23 \text { and } \\
24-35\end{array}$ & $\begin{array}{c}119(54.3 \% \text { from } \\
219)\end{array}$ & $36(16.4 \%$ from $219 / 79.3 \%$ from 46$)$ & $\begin{array}{c}155 \\
(70.78 \%)\end{array}$ \\
\hline $\begin{array}{c}36-55 \text { and } \\
56-70\end{array}$ & $60(27.4 \%)$ & $10(4.6 \%$ from $219 / 21.7 \%$ from $46 \%)$ & $\begin{array}{c}70 \\
(31.96 \%)\end{array}$ \\
\hline Total & $179(81.7 \%)$ & $46(21 \%$ from $219 / 100 \%)$ & $\begin{array}{c}219 \\
(100 \%)\end{array}$ \\
\hline
\end{tabular}

The sixteenth question was a single-choice question, the fifth question was a multiplechoice question.

Thus, the fifth hypothesis was confirmed - young people from the age groups 16-23 and 24-35, in addition to personal car and public transport, use means of personal mobility (bicycle, scooter and other means of personal mobility) more often than people of middle and elderly age $(36 / 10)$.

In general, among all respondents, there is a predominance of those who choose cabs as a means of mobility to move around the city, in addition to personal car and public transport (bus, trolleybus, streetcar, metro), rather than bicycle, scooter or other personal mobility means $(81,7 \%$ / $21 \%)$.

Hypothesis 6. With the apparent ineffectiveness of widening the existing roads by adding lanes as a means of combating traffic jams, there will be more respondents with an intermediate level of education who will consider this measure to be effective or rather effective in combating urban traffic jams than the same respondents with higher education.

Let us check with the help of cross-grouping (two-dimensional table) whether our sixth hypothesis has been confirmed in the course of our questionnaire (Table 8).

Table 8. Two-dimensional table for testing hypothesis 6.

\begin{tabular}{|c|c|c|c|}
\hline \multirow{2}{*}{$\begin{array}{c}\text { 19. Specify your current } \\
\text { level of education. }\end{array}$} & \multicolumn{3}{|c|}{$\begin{array}{c}\text { 12. Evaluate the effectiveness of the following measures to } \\
\text { reduce traffic congestion. [Expansion of existing highways] }\end{array}$} \\
\cline { 2 - 4 } & $\begin{array}{c}\text { Effective / Rather } \\
\text { Effective }\end{array}$ & $\begin{array}{c}\text { Rather Inefficient / } \\
\text { Ineffective }\end{array}$ & Total \\
\hline $\begin{array}{c}\text { General secondary }(11 \\
\text { grades at school)/ }\end{array}$ & & & \\
$\begin{array}{c}\text { Secondary vocational } \\
\text { (college. technical school. } \\
\text { college) / Incomplete } \\
\text { secondary vocational / } \\
\text { Incomplete higher }\end{array}$ & $88(44 \%$ from 200$)$ & $\begin{array}{c}11(5.5 \% \text { from } 200 / \\
73.3 \% \text { from } 15)\end{array}$ & $99(49.5 \%)$ \\
\hline $\begin{array}{c}\text { Higher (diploma of } \\
\text { specialist. bachelor. master) } \\
\text { Postgraduate. scientific } \\
\text { degree. rank }\end{array}$ & $97(48.5 \%)$ & $4(2 \%$ from $200 /$ & $101(50.5 \%)$ \\
\hline Total & $185(92.5 \%)$ & $15(7.5 \%$ from $200 /$ & $200(100 \%)$ \\
\hline
\end{tabular}

Both questions had a single answer choice.

Thus, the sixth hypothesis was not confirmed - the respondents with secondary education, who consider the expansion of the existing roads as an effective measure to combat traffic jams, turned out to be less than the same respondents with higher education (11/4). 
Overall, among all the respondents the part of the respondents who consider the extension of the existing roads to be an effective or rather effective measure to fight the traffic congestion prevails $(92,5 \% / 7,5 \%)$.

Hypothesis 7. The majority of respondents who own or intend to buy a personal car within a few years are against the authorities' enforcement measures to reduce the use of the personal car as the main means of transportation in the city.

Let us check with the help of cross-grouping (Two-dimensional table) whether our seventh hypothesis is confirmed by the questionnaire (Table 9).

Table 9. Two-dimensional table for testing hypothesis 7.

\begin{tabular}{|c|c|c|c|}
\hline \multirow[b]{2}{*}{$\begin{array}{l}\text { 1. Do you own a } \\
\text { personal vehicle or } \\
\text { do you intend to } \\
\text { purchase one in the } \\
\text { next few years? }\end{array}$} & \multicolumn{2}{|c|}{$\begin{array}{l}\text { 13. What measures should be taken by the city } \\
\text { authorities to reduce the use of the private car? }\end{array}$} & \multirow[b]{2}{*}{ Total } \\
\hline & $\begin{array}{c}\text { Authorities should use } \\
\text { certain measures to reduce } \\
\text { personal car use } \\
\text { (increasing taxes on cars; } \\
\text { narrowing roads; paid } \\
\text { parking; creating effective } \\
\text { alternatives) }\end{array}$ & $\begin{array}{l}\text { The authorities do not } \\
\text { need to influence the } \\
\text { use of a personal car }\end{array}$ & \\
\hline $\begin{array}{l}\text { I have a personal car / } \\
\text { I do not have a } \\
\text { personal car. but I } \\
\text { intend to buy one in } \\
\text { the next few years }\end{array}$ & $\begin{array}{l}78(39 \% \text { from } 200 / 60.5 \% \\
\text { from } 129)\end{array}$ & $\begin{array}{c}51(25.5 \% \text { from } 200 / \\
39.5 \% \text { from } 129)\end{array}$ & $\begin{array}{c}129 \\
(64.5 \% \\
\text { from } 200 \\
100 \%)\end{array}$ \\
\hline $\begin{array}{l}\text { I do not have a } \\
\text { personal car. but I do } \\
\text { not exclude the } \\
\text { possibility of } \\
\text { acquiring one in the } \\
\text { future / I do not have } \\
\text { a personal car and will } \\
\text { not acquire it } \\
\end{array}$ & $59(29.5 \%)$ & $12(6 \%)$ & $\begin{array}{c}71 \\
(35.5 \%)\end{array}$ \\
\hline Total & $137(68.5 \%)$ & $63(31.5 \%)$ & $\begin{array}{c}200 \\
(100 \%)\end{array}$ \\
\hline
\end{tabular}

The results of cross-grouping showed that 200 answers were given to questions 1 and 13 each, i.e. exactly the number of people who took the survey (question 1 was with a single choice of the answer option; question 13 was with multiple choice).

Thus, the seventh hypothesis was not confirmed - the majority of respondents, who either have a car or intend to buy one within a few years, believe that the authorities should use certain measures to reduce the use of personal cars (increasing taxes on cars; narrowing roads; paid parking lots; creating effective alternatives) (78/51). At the same time, the same trend (in an even more stable form) can be observed among respondents who do not own a personal car and either do not rule out acquiring one in the future or do not intend to acquire one at all $(59 / 12)$.

Overall, the majority of respondents believe that the authorities should use some measures to reduce the use of a personal car $(68,5 \% / 31,5 \%)$.

Hypothesis 8 . Family people are more likely to choose a personal car as the only possible way to get around town.

Let us check with cross-grouping (Two-dimensional table) whether our eighth hypothesis was confirmed in the questionnaire (Table 10). 
Table 10. Two-dimensional table for testing hypothesis 8 .

\begin{tabular}{|c|c|c|c|}
\hline \multirow[b]{2}{*}{$\begin{array}{l}\text { 17. Specify your } \\
\text { marital status. }\end{array}$} & \multicolumn{2}{|c|}{$\begin{array}{l}\text { 8. Are you willing to use only public } \\
\text { transportation to get around the city? }\end{array}$} & \multirow[b]{2}{*}{ Overall } \\
\hline & $\begin{array}{c}\text { Yes (either public } \\
\text { transportation meets } \\
\text { all needs. or public } \\
\text { transportation will be } \\
\text { combined with other } \\
\text { means of } \\
\text { transportation) }\end{array}$ & $\begin{array}{l}\text { No. the respondent } \\
\text { will only use a } \\
\text { personal car for all } \\
\text { his movements } \\
\text { around the city }\end{array}$ & \\
\hline $\begin{array}{l}\text { Single (not married) / } \\
\text { In a relationship }\end{array}$ & $76(38 \%$ from 200$)$ & $37(18.5 \%)$ & $113(56.5 \%)$ \\
\hline $\begin{array}{l}\text { Married (married) / } \\
\text { Married (married) } \\
\text { and have children }\end{array}$ & $\begin{array}{c}36(18 \% \text { from } 200 \\
41.4 \% \text { from } 87)\end{array}$ & $\begin{array}{c}51(25.5 \% \text { from } 200 ; \\
58.6 \% \text { from } 87)\end{array}$ & $\begin{array}{l}87(43.5 \% \text { from } \\
200 / 100 \%)\end{array}$ \\
\hline Total & $112(56 \%)$ & $88(44 \%)$ & $200(100 \%)$ \\
\hline
\end{tabular}

The results of cross-grouping showed that 200 answers were given to questions 8 and 17 , i.e. exactly the number of people who took the survey (both questions were with a single choice of the answer option).

Thus, the eighth hypothesis was confirmed - family people prefer to use only a private car for moving around the city $(35 / 51)$.

At the same time, the majority of non-family respondents are ready to use either only public transport or a combination of public transport and other alternative means of urban mobility when moving around the city $(76 / 37)$.

Overall, among the 200 respondents, the proportion who do not prefer to use a private car to get around the city prevails $(56 \% / 44 \%)$.

Hypothesis 9. People without higher education do not understand the importance of developing public transportation in the city as a measure to reduce traffic congestion.

Let us check with cross-grouping (Two-dimensional table) whether our ninth hypothesis was confirmed in the survey (Table 11).

Table 11. Two-dimensional table for testing hypothesis 9 .

\begin{tabular}{|c|c|c|c|}
\hline \multirow[t]{2}{*}{$\begin{array}{l}\text { 19. Specify your current } \\
\text { level of education. }\end{array}$} & \multicolumn{2}{|c|}{$\begin{array}{l}\text { 12. Evaluate the effectiveness of the } \\
\text { following measures to reduce traffic } \\
\text { congestion. [Development of public } \\
\text { transportation] }\end{array}$} & \multirow[t]{2}{*}{ Overall } \\
\hline & $\begin{array}{l}\text { Effective / Rather } \\
\text { Effective }\end{array}$ & $\begin{array}{c}\text { Ineffective / Rather } \\
\text { ineffective }\end{array}$ & \\
\hline $\begin{array}{l}\text { General secondary (11 grades } \\
\text { at school) / Secondary } \\
\text { vocational (college. technical } \\
\text { school. college) / Incomplete } \\
\text { secondary vocational / } \\
\text { Incomplete higher }\end{array}$ & $\begin{array}{c}74 \text { (37\% from } 200 / \\
74.8 \% \text { from } 99)\end{array}$ & $\begin{array}{l}25(12.5 \% \text { from } 200 \\
/ 25.2 \% \text { from } 99)\end{array}$ & $\begin{array}{c}99(49.5 \% \\
\text { from } 200 / \\
100 \%)\end{array}$ \\
\hline $\begin{array}{c}\text { Higher (diploma of specialist. } \\
\text { bachelor. master) / Post- } \\
\text { graduate course. scientific } \\
\text { degree. rank }\end{array}$ & $\begin{array}{c}47(23.5 \% \text { from } 200 / \\
46.5 \% \text { from } 200)\end{array}$ & $\begin{array}{c}54(27 \% \text { from } 200 / \\
53.5 \% \text { from } 101)\end{array}$ & $\begin{array}{c}101(50.5 \% \\
\text { from } 200 / \\
100 \%)\end{array}$ \\
\hline Total & $121(60.5 \%$ from 200$)$ & $79(39.5 \%$ from 200$)$ & $200(100 \%)$ \\
\hline
\end{tabular}

The results of cross-grouping showed that questions 12 and 19 were answered by 200 people each, that is, exactly the number of people who took the survey (question 19 was with a single choice of an answer option; within question 12 we consider only one of its items, which was with a single choice of an answer option). 
Thus, the ninth hypothesis was not confirmed - people without higher education understand the importance of developing public transportation as a measure to reduce traffic congestion (74/25). At the same time, the majority of people with higher education, on the contrary, consider the development of public transport as an ineffective measure to reduce traffic jams, not understanding the importance of the development of this means of urban mobility ( 47 / 54).

Overall, among the 200 respondents, the part that considers the development of public transport as an effective measure to reduce traffic congestion prevails $(60,5 \% / 39,5 \%)$.

Hypothesis 10. Respondents' income level affects residents' willingness to forego using a personal vehicle to get around the city.

Let us check with the help of cross-grouping (Two-dimensional table) whether our tenth hypothesis is confirmed by the questionnaire (Table 12).

Table 12. Two-dimensional table for testing hypothesis 10 .

\begin{tabular}{|c|c|c|c|}
\hline \multirow[b]{2}{*}{$\begin{array}{l}\text { 20. Specify your } \\
\text { financial situation. }\end{array}$} & \multicolumn{2}{|c|}{$\begin{array}{l}\text { 2. Under what conditions would you refuse to use (or } \\
\text { buy) your own car? }\end{array}$} & \multirow[b]{2}{*}{ Total } \\
\hline & $\begin{array}{l}\text { I want to have a } \\
\text { car anyway }\end{array}$ & $\begin{array}{l}\text { I will give up using a car under } \\
\text { certain circumstances (increase in } \\
\text { car prices/maintenance; increase in } \\
\text { car taxes; creation of alternative } \\
\text { means of transportation; } \\
\text { unwillingness to have a car) }\end{array}$ & \\
\hline $\begin{array}{l}\text { Financial situation in } \\
\text { one way or another } \\
\text { does not allow the } \\
\text { purchase of a private } \\
\text { car } \\
\end{array}$ & $\begin{array}{c}67 \text { (33.5\% from } \\
200 / 64.4 \% \text { from } \\
104)\end{array}$ & 78 (39\% from $200 / 81.2 \%$ from 96$)$ & $\begin{array}{c}145 \\
(72.5 \%)\end{array}$ \\
\hline $\begin{array}{l}\text { Enough money to buy } \\
\text { a private car. but it is } \\
\text { difficult to buy real } \\
\text { estate }\end{array}$ & $\begin{array}{c}28(14 \% \text { from } \\
200 / 26.9 \% \text { from } \\
104)\end{array}$ & 12 ( $6 \%$ from $200 / 12.5 \%$ from 96$)$ & $40(20 \%)$ \\
\hline $\begin{array}{c}\text { No financial } \\
\text { difficulties. but it is } \\
\text { possible to buy real } \\
\text { estate if necessary. }\end{array}$ & $\begin{array}{c}9(4.5 \% \text { from } \\
200 / 8.7 \% \text { from } \\
104)\end{array}$ & $6(3 \%$ from $200 / 6.3 \%$ from 96$)$ & $15(7.5 \%)$ \\
\hline Total & $104(52 \%)$ & $96(48 \%)$ & $\begin{array}{c}200 \\
(100 \%)\end{array}$ \\
\hline
\end{tabular}

The results of cross-grouping showed that 200 answers were given to questions 2 and 20 , i.e. exactly the same number of people who took the survey (question 2 was with multiple choice of answers, question 20 was with a single choice of the answer option).

When we refer to the bivariate table, we can see that the dynamics of respondents' answers distribution varies depending on the financial situation of the survey participants. Thus, it is observed that among the respondents whose financial situation does not allow them to purchase a personal car to some extent, the share of the answers confirming their readiness to refuse to use a personal car under certain conditions prevailed. In the groups of respondents with incomes higher than in the previous group, the answer that said they were not ready to refuse the use of a private car prevailed.

Thus, by applying a bivariate table, we have revealed that our hypothesis is confirmed respondents with an income level that does not allow them to buy a personal car, in their relative majority are inclined to be ready to refuse to use a personal car under certain conditions, while in the group of respondents with an income that allows them to buy a personal car, the distribution is already the opposite - the number of people not ready to refuse to use a personal car prevails. 
Hypothesis 12. Such categories of respondents as students and working students use public transport services to get around the city more often than others.

Let us check with the help of cross-grouping (Two-dimensional table) whether our twelfth hypothesis is confirmed by the questionnaire (Table 13).

Table 13. Two-dimensional table for testing hypothesis 12 .

\begin{tabular}{|c|c|c|c|c|c|c|}
\hline \multirow{2}{*}{$\begin{array}{l}\text { 4. How often } \\
\text { do you use } \\
\text { public } \\
\text { transportation } \\
\text { to get around } \\
\text { the city? }\end{array}$} & \multicolumn{6}{|c|}{ 18. Specify your type of activity } \\
\hline & Student & $\begin{array}{l}\text { Student } \\
\text { working }\end{array}$ & Employed & Unemployed & Retired & total \\
\hline $\begin{array}{c}\text { Very often } \\
\text { (more than } \\
\text { three times a } \\
\text { day) / Often } \\
\text { (once or twice } \\
\text { a day) }\end{array}$ & $\begin{array}{c}52(26 \% \\
\text { from } 200 \\
/ 78.8 \% \\
\text { from } 66)\end{array}$ & $\begin{array}{c}16(8 \% \\
\text { from } 200 / \\
57.1 \% \\
\text { from } 28)\end{array}$ & $\begin{array}{c}26(13 \% \\
\text { from } 200 / \\
26.8 \% \text { from } \\
97)\end{array}$ & $\begin{array}{c}5(2.5 \% \text { from } \\
200 / 62.5 \% \\
\text { from } 8)\end{array}$ & $0(0 \%)$ & $\begin{array}{c}99 \\
(49.5 \%)\end{array}$ \\
\hline $\begin{array}{c}\text { Sometimes } \\
\text { (once every } \\
\text { few days) / } \\
\text { Rarely (once } \\
\text { every few } \\
\text { weeks) } \\
\end{array}$ & $\begin{array}{c}13(6.5 \% \\
\text { from } 200 \\
/ 19.7 \% \\
\text { from } 66)\end{array}$ & $\begin{array}{c}10(5 \% \\
\text { from } 200 / \\
35.7 \% \\
\text { from } 28)\end{array}$ & $\begin{array}{c}59(29.5 \% \\
\text { from } 200 / \\
60.8 \% \text { from } \\
97)\end{array}$ & $\begin{array}{c}3(1.5 \% \text { from } \\
200 / 37.5 \% \\
\text { from } 8)\end{array}$ & $\begin{array}{l}1(0.5 \% \\
\text { from } \\
200 / \\
100 \% \\
\text { from } 1)\end{array}$ & $\begin{array}{c}86 \\
(43 \%)\end{array}$ \\
\hline Never & $\begin{array}{c}1(0.5 \% \\
\text { from } 200 \\
/ 1.5 \% \\
\text { from } 66)\end{array}$ & $\begin{array}{c}2(1 \% \\
\text { from } 200 / \\
7.2 \% \\
\text { from } 28)\end{array}$ & $\begin{array}{c}12(6 \% \\
\text { from } 200 \\
/ 12.4 \% \\
\text { from } 97)\end{array}$ & $0(0 \%)$ & $0(0 \%)$ & $\begin{array}{c}15 \\
(7.5 \%)\end{array}$ \\
\hline Total & $66(33 \%)$ & $28(14 \%)$ & $97(43.5 \%)$ & $8(4 \%)$ & $1(0.5 \%)$ & $\begin{array}{c}200 \\
(100 \%)\end{array}$ \\
\hline
\end{tabular}

The results of cross-grouping showed that questions 4 and 18 were answered by 200 respondents each, which is exactly the number of people who took the survey (both question 4 and question 18 were single-choice).

Question 4 was answered by 66 student respondents (33\% of 200), 28 working students (14\% of 200), 97 employed residents (43.5\% of 200), 8 residents who were unemployed (4\% of 200$)$, and 1 retiree $(0.5 \%$ of 200$)$.

Bivariate table shows a clear picture, in which very often (more than three times a day) or often (once or twice a day) within the territory of Kazan city is moved by public transport services mostly by such category of residents as students $(78,8 \%$ of the total number of respondents-students). In second place in terms of frequency of travel by public transport is the category of unemployed respondents $(62,5 \%$ of the total number of respondents with unemployed status). In third place are the students who combine study and work, in the share of $57,1 \%$ of the total number of such respondents.

Thus, we can summarize that the interpretation of the results of the bivariate table confirmed our hypothesis by half: among frequent users of public transport in Kazan such category of the population as students really prevails. However, the share of working students, who often use public transport, is less than the share of unemployed residents, who often use the services of public transport.

The content analysis allowed us to determine that as a result of the annual rapid growth of the number of personal cars used as a means of transportation in the city, the residents of Kazan, the local authorities are faced with the most pressing issue of the introduction of restrictive measures for motorists, due to the negative impact of the large flow of cars on the comfortable living conditions in the city. 
Over the past few years, developed countries have demonstrated a successful experience of partial/full renunciation of car use in the city/specific urban area.

There are four main trends that may determine the vector of development of Russian cities in relation to the problem of the possible abandonment of the use of private cars and the transition to public transport by citizens.

The main one is the objective and every year growing need to reduce the number of private cars and cases of their use in modern cities. Cars take up too much space, they require infrastructure, which has a negative impact on the urban environment.

The second trend is insufficient development of public transport in many Russian cities, using Kazan as an example. Thus, due to the dense flow of cars, undeveloped interchanges and lack of additional lanes exclusively for public transport, boarding and disembarking passengers cannot always be carried out properly. One of the reasons for the unsatisfactory state of public transport people also include the untimely renewal of existing vehicles and repairs. Also at certain hours, citizens note the lack of public transport on certain routes, resulting in a significant increase in travel time.

The third trend is related to the prospect of the introduction of completely free public transport, thanks to the introduction of an additional tax on motorists.

The fourth trend is an increase in the proportion of citizens who are ready to switch to public transport.

The willingness to switch to public transport is also due to the awareness of environmental problems arising in particular from the intensive use of private cars.

Based on the content analysis we can assume that the increasing need to reduce the number of cars in the near future will lead to the introduction of restrictive measures for motorists who prefer to use private cars as the main means of transport in the city. However, the unsatisfactory state of public transport may cause dissatisfaction on the part of citizens with these measures, so it is necessary to increase funding for the renewal of public transport and modernization of routes.

We consider the initiative of introducing free travel on public transport to be ineffective, as it may adversely affect the condition of the transport fund.

It is also worth noting that residents are ready to give up their personal vehicles in favor of public transport in the case of increasing the comfort of using the latter.

Thus, the main recommendation for local authorities is to implement a policy to modernize the transport fund and improve transportation routes in conjunction with the gradual introduction of restrictive measures for motorists.

After completing the study, we compiled a list of recommendations. But before proceeding to it, let us analyze the possible reasons for city residents to buy and use a personal car.

The first reason in favor of the car is the weather conditions in which most Russians have to live. Many drivers say that in a milder climate they could do without a car, but in winter it is too cold to stand at a bus stop, which means that a car is the only way out. The second argument is city size and distance. Car owners point out that moving long distances is impossible without a car. The third reason is the level of development of public transport. Car owners are dissatisfied with its congestion and irregularity. In some cities there is not enough public transport. The fourth factor in favor of the car is the status which the car gives to the owner. And finally, in favor of the car says comfort, which is difficult to provide in public transport.

And now let us consider the reasons why it is more profitable and rational for city dwellers to refuse to use a private car for their movements around the city. The first argument in favor of public transportation is the cost of car care. You don't just have to buy a car and fill it up regularly: the car owner will be faced with payments to insurance companies, preparations for maintenance inspections, tire and oil changes, and many other 
expenses that a public transportation passenger would never incur. The second reason is the environmental impact of cars. Where the emissions of poisonous substances would leave a hundred passenger cars, there could be one bus (that is, we are talking about minimizing the impact on the environment). The third point in favor of public transportation is the comfort and quality of life of the people around them. Often people do not realize that their ownership and use of a private car in the city can cause discomfort to other residents. The fourth argument is the time savings that occur to a person without a car. The pedestrian passenger does not have to think about where to park and how to maintain their car, there is no problem of long-term storage. The fifth argument lies in the plane of psychology: motorists have to go through more stress because of not always correct behavior of other drivers and the prospect of meeting with an inspector of the traffic police.

For many, it is this factor that becomes the key factor in giving up a personal car.

Thus, having briefly considered two points of view, we can observe that each has the right to exist and its evidence base of arguments. Therefore our recommendations will be aimed at eliminating the reasons, which can make city dwellers want to own and use a personal car for their movements:

1) Eliminate the possible negative impact of weather conditions for moving around the city without a personal vehicle. This will not require the development of anything special, it will be enough to provide public transport with heating during the winter season, so that passengers feel comfortable by choosing this mode of transport. It will also be necessary to work out the stationary infrastructure of public transport to function in winter. For example, to provide stops with heating in cold weather, to make them closed from wind, snow and other weather conditions, to maintain a comfortable temperature for people.

2) To provide within the city a developed network of public transport for unimpeded movement to any point of the city. For this purpose it will be enough to create several routes using different types of public transport along the most demanded ways of movement of the city residents, as well as to provide an opportunity to use at least one type of public transport for each resident regardless of which part of the city he/she is located in. In many ways public transport can be improved and made more versatile for moving around the city by interchange hubs, where a passenger can conveniently combine different modes of public transport when moving from point A to point B.

3) Invest the budget in the creation and functioning of public transport that meets all the needs of modern man (in comfort, in the speed of travel, in price, in accessibility of use, etc.). Often in Russia little importance is attached to public transport, especially in small towns, as a result of which it is in a neglected state and cannot meet the needs of residents, looks unattractive in their eyes. This problem can be solved by increasing funding for public transport and implementing programs for its development.

4) To give up the stereotypes of owning a private car. A private car is first of all a means of transportation. Now is not the XX century and having a personal car will not surprise anyone. People must stop considering a car as something special and vital for purchase, the refusal of which would be critical both for comfortable life and for the reputation of the person. In today's world, even well-to-do people may not feel disadvantaged in any way by using public transport (provided it is properly developed).

5) Create a network of public transport, not inferior to the comfort of using a private car to move around the city. It is possible to solve this task in many ways, including those already repeatedly mentioned earlier. For example, it is necessary to regularly monitor the condition of the rolling stock, to carry out in due time repairs and replacement with newer and more modern models. It is necessary to create conditions in which the use of public transport will be more attractive than the use of a private car. In Russia, unfortunately, a lot of attention is currently paid to the comfort of car owners (roads are widened, new lanes are added, new roads are built, the number of parking lots is increased, the maximum allowed 
speed is not reduced, etc.), while in the modern world it is more important to pay attention to the comfort of public transport passengers. This statement is true for many reasons. Firstly, it is impossible to create a city that is comfortable only for motorists. The experience of many cities in different countries in the second half of the twentieth century shows that. In any case, in the process of growth and development of the city, there will be a situation when there will be too many cars in it. That is why there is a tendency in all cities of developed countries to reduce the use of private cars and to develop public transport. Secondly, in any city, there are significantly more people using public transport than car owners. Thirdly, a large proportion of the population consists of people who cannot use a private car for their travels due to a number of circumstances (insufficient income, advanced age, diseases, etc.). This group of city residents in the absence of public transport becomes completely immobile and socially unprotected by the state in matters of movement around the city.

\section{Conclusions}

As a result of our study, we have found that at the moment within the city of Kazan there is indeed a problem, which we put forward in the methodological part of the study and consists in the inability to ensure at present the universal transition of residents from the use of private cars to the consumption of public transport services, due to the lack of development of appropriate infrastructure. Although there is an awareness of the need for such a process among Kazan residents.

Collecting and analyzing the opinions of a sample of 200 people from 16 to 71 years old Kazan residents of both sexes, with different marital and financial status, educational level and main occupation, through questionnaires, allowed to obtain the basis for a number of conclusions:

1) For $88 \%$ of questioned Kazan citizens a personal car is an obligatory attribute of life in the city;

2) $7,5 \%$ of respondents have absolutely no desire to use a private car today;

3) $52 \%$ of total number of questioned inhabitants would like to have any car under any circumstances;

4) Financial measures (increase in car prices, increase in car service prices, increase in transportation tax) will be unsuccessful in forming incentives in the minds of Kazan residents to refuse to use private cars, while actions to provide citizens with decent alternatives for getting around the city have a chance to succeed;

5) $25 \%$ of respondents never use public transport to get around the city;

6) Movement by means of individual mobility (bicycle, scooter, etc.) is quite unpopular among the respondents as an alternative to moving in a private car;

7) The most popular among the respondents of Kazan have such modes of public transport as bus, metro and cab; a much smaller number of respondents showed their loyalty to the trolleybus and streetcar;

8) The majority of respondents noted that they are rather satisfied with such factors of public transport of the city as the fare, condition of transport, professionalism of conductors and drivers and comfort and speed of travel, and definitely satisfied with the availability of this type of transport

9) At the moment only half of the respondents are ready for full transition to public transport (with or without the additional use of personal mobility);

10) The most important factors in full transition to public transport for the respondents are the price of the trip and the number of routes; 
11) For most respondents from among those who are more or less loyal to the idea of the possibility to move around the city by bicycle or scooter the decisive aspect in choosing these modes of transport is the sufficiency of pedestrian zones and bicycle lanes;

12) $55 \%$ of respondents in Kazan stated that they periodically encounter the problem of traffic jams on Kazan roads in their lives;

13) Along with measures to develop public transport services, the participants of our survey consider measures to expand existing roads and the construction of new ones to be effective in the fight against traffic jams in the city;

14) The ideas about the need to influence the authorities to reduce the use of personal cars by creating decent alternative means of transportation and, on the other hand, about the unnecessary participation of the authorities in controlling the use of personal cars are equally popular among the respondents;

15) Kazan residents are aware of the importance and necessity of developing public transport, but are not ready to switch to it and give up using their own cars, citing the more difficult travel through the city and the possible negative impact on emotional health and climatic conditions;

16) The majority of residents do not believe that reducing the use of the personal automobile will increase the attractiveness of the city and reduce the costs of moving around the city for residents;

The readiness of the residents to refuse using a private car in favor of public transport (which already exists but needs to be stimulated) should be supported by the local authorities by gradual introduction of restrictive measures for motorists together with simultaneous implementation of measures to improve the transport fund and optimization of transportation routes needed to prevent potential aggravation of the situation on the roads at the moments of the most intensive traffic.

\section{References}

1. N. Ding, J. Pana, Zh. Zhang, J. Yang, Science of The Total Environment 688, 11371144 (2019) https://doi.org/10.1016/j.scitotenv.2019.06.111

2. P. Jochem, D. Frankenhauser, H. Fromm, Transportation Research Part A: Policy and Practice 141, 373-395 (2020) https://doi.org/10.1016/j.tra.2020.09.016

3. M. de-Miguel-Molina, B. de-Miguel-Molina, D. Catalá-Pérez, Research in $\begin{array}{llllll}\text { Transportation Business \& } & 100503 \quad \text { (2020) }\end{array}$ https://doi.org/10.1016/j.rtbm.2020.100503

4. K. Čulík, A. Kalašová, Z. Otahálová, Transportation Research Procedia 44, 240-247 (2020) https://doi.org/10.1016/j.trpro.2020.02.047

5. A. Urbanek, Research in Transportation Economics 85, 101008 (2021) https://doi.org/10.1016/j.retrec.2020.101008

6. A. Andersson, L.W. Hiselius, E. Adell, Transport Policy 90, 22-30 (2020) https://doi.org/10.1016/j.tranpol.2020.02.006

7. C. Bayart, N. Havet, P. Bonnel, L. Bouzouina, Transportation Research Part D: $\begin{array}{llll}\text { Transport and } \quad \text { Environment } & 102235 & \text { (2020) }\end{array}$ https://doi.org/10.1016/j.trd.2020.102235

8. A. Gundlach, M. Ehrlinspiel, S. Kirsch et al, Transportation Research Part D: $\begin{array}{lllll}\text { Transport and } & \text { Environment } & \text { 63, }\end{array}$ https://doi.org/10.1016/j.trd.2018.07.004

9. G. Tiwari, C. Phillip, IATSS Research 3 https://doi.org/10.1016/j.iatssr.2021.02.002 
10. V. Uskov, O. Kharchenko, Transportation Research Procedia 54, 645-653 (2021) https://doi.org/10.1016/j.trpro.2021.02.117

11. A.P. Rudke, J.A. Martins, A.M. Santos et al, Journal of Transport Geography 91, 102975 (2021) https://doi.org/10.1016/j.jtrangeo.2021.102975

12. Currie, G., Fournier, N.: Valuing public transport customer experience infrastructureA review of methods \& application. Research in Transportation Economics 83, 100961 (2020) https://doi.org/10.1016/j.retrec.2020.100961

13. M. Stryhul, O. Khomeriki, O. Mykhailych et al, Transportation Research Procedia 54, 610-616 (2021) https://doi.org/10.1016/j.trpro.2021.02.113

14. Ch. Weckström, M.N. Mladenović, Transportation Research Procedia 45, 979-986 (2020) https://doi.org/10.1016/j.trpro.2020.02.068

15. T. Suguiy, M.F. Henriques de Carvalho, P.A.V. Ferreira, Case Studies on Transport Policy 8, 938-945 (2020) https://doi.org/10.1016/j.cstp.2020.05.003

16. A. Andersson, Transportation Research Part D: Transport and Environment 78, 102198 (2020) https://doi.org/10.1016/j.trd.2019.11.027

17. B.T.H. Yen, C. Mulley, M. Zhang, Transport Policy 95, 68-77 (2020) https://doi.org/10.1016/j.tranpol.2020.06.001

18. N. Pavón, L.I. Rizzi, Transportation Research Part A: Policy and Practice 125, 89-105 (2019) https://doi.org/10.1016/j.tra.2019.05.001

19. Sh. Sinha, H.M.Sh. Swamy, Kh. Modi, Transportation Research Procedia 48, 33103323 (2020) https://doi.org/10.1016/j.trpro.2020.08.121

20. M.A. Saleem, L. Eagle, D. Low, Transportation Research Part D: Transport and Environment 59, 68-85 (2018) https://doi.org/10.1016/j.trd.2017.12.023

21. G. Tonn, A. Reilly, J. Czajkowski, et al, Transport Policy 100, 108-119 (2021) https://doi.org/10.1016/j.tranpol.2020.10.011

22. Y. Sun, Y. Cui, Transport Policy 66, 116-126 (2018) https://doi.org/10.1016/j.tranpol.2018.02.006

23. N. Giuffrida, M. Le Pira, G. Inturri, M. Ignaccolo, Case Studies on Transport Policy 9 , 12-21 (2021) https://doi.org/10.1016/j.cstp.2020.06.008

24. S. Maas, P. Nikolaou, M. Attard, L. Dimitriou, Transportation Research Procedia 52, 565-572 (2021) https://doi.org/10.1016/j.trpro.2021.01.067

25. Ch. Liu, A. Tapani, I. Kristoffersson et al, Case Studies on Transport Policy 9, 125-136 (2021) https://doi.org/10.1016/j.cstp.2020.11.003

26. I.P. Teixeira, A.N. Rodrigues da Silva, T. Schwanen, et al, Journal of Transport Geography 88, 102830 (2020) https://doi.org/10.1016/j.jtrangeo.2020.102830 